\title{
A Scientific Approach to Flat-For-Land Basis Model in an Urban Transformation Project: Beyoğlu Okmeydanı
}

\begin{abstract}
\section{Purpose}

Contribution to our country's urban transformation application literature was aimed via the transformation and mathematical distribution model which was developed considering the unique properties of Okmeydanı Urban Transformation Area, which was officially declared as "risk area" by the Cabinet.
\end{abstract}

\section{Design/Methodology/Approach}

After the Introduction, information about the emergence, definition, purpose, and differences in the historical application of the concept of urban transformation were given. The changes of urban transformation practices and their reflections on the cities since 1950s in Turkey were analyzed on the basis of urban transformation experiences and practices in the developed countries. Financial methods used in transformation projects were discussed in detail by taking the current urban transformation law and policies into consideration. On the third section, physical, social, and economic data regarding the City of Istanbul, Country of Beyoğlu, Okmeydanı Urban Transformation area, which is the main topic of this study were presented in detail. The
Keywords: urban transformation, urban regeneration, flat for land basis model, Beyoğlu, Okmeydanı

*Ph.D in Urban and Regional Planning department in İstanbul Technical University, İstanbul

Email: ufukaltunbas@yandex.com https://orcid.org/0000-0002-0905-9151 
urban transformation and distribution model which was developed based on the technical data, community requests, and official data was described in detail with its formulas. In the conclusion section, the reflections of the model on both the area itself and on the city were evaluated.

\section{Findings}

In accordance with the analysis conducted based on the current settlement, the size of the population, and the zoning plan of the urban transformation area; it is inevitable for the rights holders to agree to a downsizing of their estates and to take action collectively. This situation makes it harder to realize the urban transformations' legal obligation of approval by at least 2/3rds of the rights holders. Furthermore, meeting of the investor's and all the rights holders' project rights on the project area will inevitably result in new urbanization problems in the future.

\section{Research Limitations/Implications}

Due to the not being able to collect enough social and economic data on Okmeydanı Urban Transformation Area, the developed transformation model was based mostly on technical and physical data. Therefore, the social evaluation, which is one of the requirements of a successful urban transformation could not be conducted.

\section{Practical Implications}

The determined urban transformation model for Okmeydanı Urban Transformation Project was developed in a transparent and egalitarian approach using the official data, supported by scientific methods, and preparing the legal background for all decisions.

\section{Social Implications}

Although the social data of the area was not one of the parameters used in the developed transformation and distribution model, the implementation of the transformation model is consistent with the social benefit expected from transformation projects since it is based on the principle of keeping the resident rights holders in their neighborhood after the completion of the project.

\section{Originality/Value}

Okmeydanı is an area that is not suitable for implementation of previous transformation models due to its ownership structure, its licensed and unlicensed constructions since 1950s, its historic past and protection status, location, population size and density, and inevitability of unified action from its residents because of the zoning plans. Therefore, a unique model that befits the unique properties of the area was developed.

\section{INTRODUCTION}

Although the concept of city has a major criterion such as the coexistence of a certain number of people, it is actually as old as the history of human beings in terms of geographic locations of different sizes, where there is communication between people. From the first settlements to the present day, all cities have been in a continuous change and transformation. This is in fact a natural consequence of urban life and conditions (Harvey, 1987). At the same time, these changes contained both chances and risks for the future of the cities. As a matter of fact, while many cities that do not keep up with the social, cultural, political, physical and economic changes in the globalized world face either degrowth or disappearance, cities that turn competition 
into opportunities have turned into big metropolises in every sense. While this transformation process took place gradually due to needs and challenges of the period in some cases, on other cases it took place with the projects realized by the human hand. Urban transformation practices, which aim to improve the physical structure in the rapidly transforming cities, prevent social and economic problems, increase economic and cultural opportunities, and develop social life for weaker groups especially children and young adults (Auerbach, 2013), have first emerged in the United States, then spread to the United Kingdom and Europe respectively (Carmon, 1999). While the urban transformation implementations had positive aims such redesigning the unplanned growth of the citites and includingthe slums and the poor living areas in the urban planning initially, later on it turned into a negative process with aims such as removal of the poor class from their living areas and introducing new functions with high economic value to these regions. This situation brings to mind the most criticized notion of "gentrification" in urban transformation literature, and urban transformation practices in all around the globe have become subjects of criticism in terms of location selection, method, purpose and results. The fact that fundemental changes caused by big urban transformation projects in the physical region change both the region and its surroundings both economically and socially is accepted by everyone. This is the biggest indicator of the fact that the practice is not only a construction activity, but also a total social engineering project that shapes the economic, social and cultural lives of the inhabitants of the city.

All positive and negative practices of the urban transformation that took place in the developed countries where it first appeared are also forms the recipies for the correct implementation from now on. In fact, these policies forms a basisin particular for developing cities, and they need to identify their own transformation policies by paying attention to the local characteristics and potentials of the city. In this context, unfortunately, the concept of urban transformation in our country is perceived only as a change of the physical structure. Illegal buildings and squatters get demolished in the classical zoning concept and high-rise buildings get constructed in accordance with development plans. Strategies that take into account the social, economic and environmental aspects of the issue are not developed. As a natural consequence of this generally accepted and preferred approach, urban transformation in our country is perceived as a rental income source by the society. In order to remove this perception and to avoid development of bigger problems due to these urban transformation processes that we witness even more often, 
development of urban transformation models that are unique to our country is inevitable for all stakeholders. Therefore providing an alternative model for urban transformation applications in similar areas was aimed in this paper. Although the model developed in this paper mostly contains mathematical parameters for the physical structure, it also puts emphasis on the social structure with its aim to keep the residents in their own locations. For Beyoğlu - Okmeydanı region, which was legally declared as an urban transformation zone in 2016, mostly theoratical and project based works have been completed, and the negotiations still go on. Demolition and construction work has been started only on a very small section of the areas with completed negotiations.

\section{CONCEPT OF URBAN TRANSFORMATION AND PERCEPTION IN TURKEY}

\section{The Emergence Of Urban Transformation And Its Historic Evolution}

The concept of urban transformation can be defined differently in terms of its purpose, method, point of view and results, since it involves more than just the physical transformation of a space. In its broadest definition, it includes all the economic, social and physical interventions for the city (Couch et al., 2003). Thomas (2003) define the urban transformation as the whole of actions that try to improve the physical, social and economic conditions of a region and try to find a permanent solution to the problems. According to Moseley (2006), urban transformation has a different meaning for everyone, it can be define as a series of processes for betterment of land, ownership and infrastructure in order to gain social, economic and environmental benefits. Couch (1990) already refers to urban transformation as an effort of the state or local people to improve the quality of life in the city.

Donnison (1993) describes the urban transformation as the path and methods of all the units of the city in order to find solutions to the problems in the city's collapse areas. With a similar definition, Roberts (2000) define urban transformation as a consensus that reveals the processes of urban deterioration and the intended results after the transformation. What is meant by a consensus is that all stakeholders agree on a targeted outcome in order to restore economic viability, establish social cohesion, and improve the quality of life in areas where economic, social and environmental problems exist.

It is possible to classify the purpose of urban transformation in different ways based on all the definitions that complement each other. Verhage (2005) classifies it in three groups as socio- 
economic, socio-cultural and physical-economic objectives. For socio-economic objectives, the aim is to obtain building typologies where individuals from various socio-economic groups can live together and to increase the activities that will boost the economic viability in the region. For socio-cultural objectives, it is essential to strengthen the social cohesion and increase the social activities and the struggle against crime rate. For physical-economic objectives, increasing the economic value by enhancing the infrastructure facilities, transportation network, public space quality and social space quality of the region and making the region attractive for the private sector come into prominence. Getting into a bit more detail than Verhage, Roberts(2000) divide the objectiveof urban transformation into 5 groups. The first one is to investigate the causes of social degradation and to take preventive measures to intercept the formation of depression areas caused by deterioration. The second is the focus on the re-planning of the urban areas according to the physical, social, economic and environmental needs that arise in the rapidly growing, changing and deteriorating texture of the city. The third objective is to introduce new development approaches to improve urban quality of life. Fourth, the development of strategies to restore vitality in places where economic viability is lost. The last one is to introduce the most effective use of urban areas and strategies to avoid unnecessary urban spread.

For all these objectives, different transformation methods have been preferred in line with the needs of the region, the conditions of the period, and the country's transformation policy. Urban renewal, revitalization, rehabilitation, redevelopment, urban clearence, regeneration, preservation, and gentrification can be counted as the foremost of these methods (Zeng et al. 2014). However, these methods actually do not have very different meanings. There are even experts who think that methods are intertwined or that one is the subheading of the other. For example, according to Clay(1979) gentrification is one of the two basic types of revitilization method. Pinar(2016) believes that gentrification is not a method of urban renewal but is essentially the result of urban renewal. Rui(2003) defines restoration, rehabilitation and redevelopment methods as subtitles of urban renewal method in his renewal matrix.

Economic, political and social factors are the most decisive elements in determining the name of these methods which are not far from each other and/or which one is preferred. In particular, the perspective of the ruling party on the issue reveals the programs and approaches to be used and shapes city policy of the country (Beswick and Tsenkova, 2002). Throughout history, urban transformation practices have been implemented 
through these factors first in the US, and then in the UK and other European countries. As a matter of fact, the interventions of Haussman in the center of Paris in the middle of the 19th century and the construction of new buildings in London after the big fire can be accepted as urban transformation practices and they were made within the framework of the political decisions of the period (Couch and Fraser, 2003).

It can be said that urban transformation practices have become a part of the urban policy as a method after World War II. Roberts (2000) divided the evolution of these policies into five periods in terms of the period after the war. Although these policies differed from country to country in historical terms, in general the dominant understanding in the 1950s was reconstruction, revitalization in the 1960s, renewal in the 1970s, redevelopment in the 1980s, and regeneration in the 1990s. Since the 2000s, the urban renaissance has entered the agenda of urban policies as a new concept originating from the UK (Lees, 2007).

After World War II, most European cities had to face reconstruction. This situation has been observed not only in urban centers but also in residential and industrial areas (Couch et al, 2013). This process is realized in 2 stages. In the first stage, it is aimed to demolish the designated area as the area of transformation, and in the second stage, it is aimed to construct new buildings. Essentially, demolition is a widely used method in the United States and England since the 1850s (Diacon, 1991). However, the reconstruction policy was started to be discussed in the 1960s due to the cost of new building construction and slum's cleaning. Experts such as Ian Nairn and Jane Jacobs joined the discussions with their criticism that the process should be conducted more humanely(Couch et al., 2013). Another criticism of the method is that the regions that most frequently face the practice of destruction are poor and ethnic regions where minorities live. In addition, similar discriminations in the allocation of housing in the new buildings caused the method to be accused of racism. In order to prevent these criticisms, legal regulations had to be made (Pacione, 2001). After all criticism and negative results, the policy of "reconstruction" has begun to be abandoned since the 1960s. The first country to give up this policy in Europe was Britain in 1957 with the Law on Housing Act (Couch et al., 2003)(Couch et al., 2011). From the 1960s onwards, the prevailing urban policy is the "revitilization" method. The emphasis is also on the economic and social aspects of settlements, not just as a physical site. Kenedy and Leonard (2001) defined the physical dimension of the new transformation policy as building and street texture quality, economic dimension as job and service opportunities, and social dimension as reducing crime and increasing job opportunities. In 
this sense, it is possible to show the historical sites as the best examples for "revitilization" method. The restoration practices in historical places ensure that the historical heritage is preserved and transferred to the generations in a physical sense, but it is insufficient to ensure the continuity of the site economically and socially. On the other hand, Oc, Heath and Tiesdell(2010) believe that the revitalization policy will provide a great contribution to the revival and sustainability of the region by introduction of new economic functions in the restoration areas and integration of identifying feautres such as the street texture in the new designs.

As a matter of fact, the subject was considered together with its social dimension with the concept of secteur Sauvegardein France (1962) and the concept of "conservation areas" (1967)in England, which are developed European countriesthatare aware of the importance of revitalization policy in historical places. The role of urban transformation in the 1970s has changed somewhat since then. The economic recession resulted in unemployment, the increase of vacant lands and the increase of migration from the city. Transformation practices have started to be used as a tool to get out of the economic bottleneck (Couch et al, 2013). The first emergence of the new urban policy called "Renewal" was in England in 1969. England was followed by the Netherlands and France in 1970 and by Germany in 1971. Although there were different approaches in each country, generally they all cooperated with the private sector(Couch and Fraser, 2003). In the 1980s, the redevelopment policy came to the fore. However, there has been no major change in general policies. Only more attention has been paid to the economic dimension of the work. Demolition and displacement applications were preferred to make better quality, economic and functional buildings by using technological facilities (Visscher et al. 2006). However, the problems experienced in the evacuation processes of the residential areas planned as a transformation region have created great obstacles in the implementation of the applications. In addition, the social and political adversities caused by these projects have made the application of "redevelopment" difficult. Because of such negativities, the 'redevelopment' policy was implemented mostly outside the city and in commercial areas. Newly produced buildings weremostly commercial buildings such as large business centers, fair areas or hotels and have contributed to the economic development of their surroundings (Koebel, 1996). The dominant policy in the 1990s was "regeneration". It is a more comprehensive, longer-term and practical policy than previous policies. Private sector, transformation-oriented agencies and voluntary funds are in cooperation with the public 
in the process. It is a process that involves experts from different disciplines and includes political, economic, social and managerial elements(Teixeira, 2010). In the 2000s, the 'regeneration' policy from England was replaced by the 'urban renaissance' policy. Although they are similar to each other in a multi-faceted way, sustainable and liveable cities are targeted in areas such as social improvement, health, crime, education, environment, energy and freedom, where more actors are together and social participation is achieved (Lees, 2007). There wasa global competition among cities through large projects (Couch et al, 2011).

\section{Urban Transformation in Turkey and the Financial Models Used}

Although the method, time and name of the policies implemented vary from country to country, it has been shaped from the perspective of finding solutions to the problems that arose in the previous practices within a certain system in developed countries. Unfortunately, it is not possible to talk about a similar system in our country. Torus and the Aydin Yönet(2016) analyze the above historically grouped and defined urban policies in three different periods for Turkey. The first one is between 1950-1980. In this period, according to statistics, the number of squatter houses in cities reached from 25,000 (1948) to 1,5 million (1983). The legalization of the squatter houses, which the state is forced to accept out of the political concerns, has started the transformation in the squatter neighborhoods. Over time, the legalized squatter houseshave been demolished and multi-storey buildings have been built (Akkar Ercan, 2013). Regeneration and rehabilitation come to the forefront in these squatterareas as a transformation policy. Thus, it is aimed to gain the squatterareas for the city in line with a certain plan. The second period is between 1980-2000. In this period, renewal, rehabilitation and preservation practices come to the fore with neo-liberal policies and the effect of globalization. Transformation practices are seen as a market tool and used by all partnersto provide economic benefits. In the previous period, the construction process, which was carried out through local contractors, gradually fell into the hands of big contractors. In the same period, some public companies, especially Public Housing Administration(TOKI), have been involved in the construction process. In addition, in 1980s and 1990s the Law for Metropolitan Municipalities No. 3030, Zoning Law No. 3194, Mass Housing Law No. 2985 and Law No. 2981 have accelerated the process by increasing the effectiveness of local governments on urban regeneration (Akkar Ercan, 2013). The third period is the period from the 2000s to the present. In this period, 
dominant policies are renewal and reconstruction. The most important issue affecting the process is the natural disasters. The shock which was created in the society upon the Marmara Earthquake of 1999 has triggered the process of urban transformation in Turkey. In particular, the demolition and renovation of the apartments has accelerated. However, after the Van earthquake in 2011, it was realized that the transformation issue could not be overcome with building renovation. The idea of approaching the subject as spatial rather than the building was supported by the central government and in 2012 the Law of Transformation of Areas Under Disaster Risk No. 6306 was enacted. Thus, the issue of urban transformation has become a country policy.In the same period, Law of Usage of Timeworn Historical and Cultural Real Property with Restoration and Protection No. 5366 (2005) facilitated the transformation process in historical places. The aim was to speed up the process in all the legislative amendments made especially in the laws numbered 5366 and 6306. In both the central government and the authority received from the center, the local government increased its cooperation with the private sector. Thus, while the public is benefiting from the financial power of the private sector, the private sector also reduces the risk thanks to the public assurance. Considering the financial dimension of the transformation projects, this cooperation has become the most important strategy of urban transformation projects for our country.

Financing is one of the most important issues in terms of urban transformation practices in developing countries like our country. Transformation especially in large areas is long-lasting due to the fact that the area of influence is not limited only to the selected area, but it concerns all segments of society socially, culturally and economically and takes important decisions about the future of the city. It is inevitable for the organization to be financiallystrong in order to prevent the practices to be interrupted within this period. This situation is solved by the participation of non-profit organizations in the multi-sectoral partnerships established in the developed countries based on upper-scale strategies, in order to increase the reliability in public, private and civil organizations as well as in expenditures (Atkinson, 2004; Hague, 2004). However, similar mechanisms have not yet been established in developing countries like ours. In our country, the number of urban transformation applications that are seen as a so called magic wand solution in order to find solutions to the problems of urbanization are increasing day by day. However, the financing of such projects by the state becomes more difficult. Revenues determined in accordance with Law No. 6306 for use in transformationpractices only consist 
of $50 \%$ of the contributions and administrative fines collected under the Environmental Law, 90\% of the sales revenue of the lands that are taken out of the forest known as 2B lands in the community, and the $\% 50$ of profits of Iller Bank(ILBANK) from certain activities. Apart from these, TOKI or public companies that do not have large profit targets are put into service. Despite all the public resources, it is not possible to make the transformation only by the state. It is inevitable to cooperate with the private sector.

The financial methods that can be used in the cooperation phase are divided into two groups as Internal and External Resource Solutions in the City Planning Council Urban Transformation Commission report (2017) organized by the Ministry of Environment and Urbanization. Internal resource solutionsare divided into 7 sub-headings, namelyflat-for-land basis, revenue sharing, based on squatter law, agreement-based, cost-based, value-based and ministerial credit subsidy; while external resource solutions are divided into 5 sub-headings, namely bond issuance, infrastructure real estate investment trust, real estate investment fund, real estate certificate, and funding from international organizations.

One of the most preferred internal financing solutions is the "floor equivalent" model. On the basis of the model, the constructed areais shared between the rightholders and the contractor accordance with the construction area stated in the zoning plans. Local government has more regulatory effectiveness since it is frequently used for building-scale transformations. "Revenue Sharing" is another preferred model. The income from the project on empty public lands is shared between public or semi-public companies such as TOKİ, İLBANK, Istanbul Residence Development Plan Industry and Trade Inc. (KIPTAŞ) and the investor. Not paying for the land initially, ease of processing, ability to sell before the end of construction and tax exemption are the most attractive propertiesof this model. In the "Squatter-law-based" model, construction on public land is demolished and construction is carried out on the rights determined in the zoning plans. The owners of the building, have the right to pay for the remaining parts of the collapsed buildings after they have been deducted from the deed and, if any, the title deed. In the Agreement based model, while the area of urban transformation is declared, the reserve area is determined. Reconciliations are made on the structures in the reserve area with rights holders and existing buildings are emptied. The new phases of these areas are then discharged and the other phases of the project are financed. In this model, both private and public institutions and companies can be employed. For Value-based model, construction size is not a criterion. Property is accepted 
as a financial input. In the model, it is essential to share the new project value between thepartnersby taking into consideration the pre-project value of the current structure, the cost of the investor including the profit and the expenses. In the ValueBased transformation model, an agreement is made on the cost of construction by the right holder and the constructor persons or institutions. One of the partners is obliged to complete the construction and the other is to pay the construction cost to the other partners. The last one of the internal financial solutions is the Ministry Loan Subsidy. In this model, the Ministry of Environment is provided with interest support for the loans to be used under the Law No. 6306 for the purpose of encouraging the transformation of risky buildings.

Although the legal arrangements have been completed in the external resource solutions, they are rarely preferred due to the length of the procedure, our country's high risk perception by international institutions in accordance with the current world political conjecture, and lack of testing by internal institutions of Turkey.

All legal arrangements and alternative financing methods show that the transformation issue has 3 important stakeholders in our country. The public sector that manages the organization from the administrative point of view, the private sector that is responsible for the finance and construction activities, and the rights holders most affected by the process. The ability of partners to act together is directly related to the success of the transformation project. In this context, a mathematical model must be put forward regardless of the preferred financial method. The most important part of the model is the conversion coefficient that determines how and to what extent rightholders can benefit from the new project. The conversion coefficient can be defined as the size/value of the rightsholders' estate against $1 \mathrm{~m} 2$ of the new building, or conversely, the area that the rightsholders can buy from the new building against their real estate's size/value. The success of the complex studies involving many actors such as urban transformation depends on the correct determination of the mathematical model and the conversion coefficients.

The most important factor in determining the method and model in the transformation practicescarried out in our country is the characteristics of the transformation area and the state of rightholders. Thus, it is not possible to talk about a general model for our cities where uncontrolled construction takes place in many different ways. However, whichever model is chosen, usually the residents of the area to be transformed do not have the necessary financial means to join in the transformation project. Accordingly, the residents can only join in via the value 
of their real estate. Although different models are used to asses the values of real estates, Yalpır(2007) classifies them in 3 main groups: traditional, statistical, and modern. Despite the differences of these methods, while the value of a real estate is sometimes assessed using environmental aspects such as distance to the city center, population density, environmental quality, noise pollution, distance to the commercial areas, transportation, location, demographic structure of the region; at other times it is assessed using the building's own parameters such as construction quality, number of rooms, parking space, age, existence of a swimming pool-elevator-parking lot, number of floors, view, ownership status and structure.

In this context, the Okmeydani Urban Transformation Project is a transformational area where it is not possible to approach the issue through mathematical methods used in the previous urban transformation practices in terms of ownership status, legal structure, demographic characteristics and location. However, as in other urban transformation areas, in Okmeydanı, the right owners only participate in the transformation project based on their real property value. Therefore, the values of real estates in Okmeydanı had to be determined by calculating both their cost and market values. However, during those calculations while some parameters had to be given more weight, some other parameters had to be ignored altogether; due to the characteristics of the area. Based on calculation results, the determinedconversion coefficients were calculated as the unit price to be used in the calculation for each $1 \mathrm{~m}^{2}$ area to be offered to the right holders from the new project. Thus, it is aimed to conduct the transformation process in the field in a proper and fast manner, and an alternative distribution model proposal has been developed to be used in transformation areas with similar characteristics.

\section{MATHEMATICAL MODEL ON TRANSFORMATION AND SHARING IN OKMEYDANI}

\section{Data on Okmeydanı Urban Transformation Area}

Okmeydanı, which is located within the boundaries of Beyoğlu district of Istanbul, dates back to the conquest of Istanbul in 1453. It is one of the three regions where Sultan Mehmed the Conquerorraised his tent in order to manage the armies in which pre-conquest war preparations were made. (Bir et al., 2006).

Okmeydanı after the conquest wasone of the oldest sports fields of the world where archery, wrestling, javelin, and track races wereperformed (Bir et al., 2006), in addition to its usage for purposes such as collective entertainment, celebrations, gathering places during disasters and epidemics. 
In addition to being a sports center, the area is an important world cultural heritage center with its monumentals, which are aesthetic masterpieces that wereerected on the grounds where the competition records were broken. While the number of these monuments were 10-12 in the beginning, by the $19^{\text {th }}$ century, their number went up to more than 300 . However, this number was determined to be 60 by the General Directorate of Foundations in 1985. Most of these monuments were destroyed bythe infrastructure activities by either being used as building foundations or getting buried under the ground. The destruction of the monuments was similar to that of the stones erected around the border of the area in the 16th century. Today, only 8 of these stones remain(Bir et. al., 2006). In order to prevent all these destructions and to bring this area of great importance to future generations, Okmeydanı has been declared as a protected area with the decision of the High Council of Immovable Monuments and Antiquities dated 06.05.1961 together with all the historical monuments including monuments and border stones. After the decision, many positive and negative decisions regarding the area were taken by the Cultural Heritage Preservation Board. With the last decision dated 15.09.2010, the 14 site areaswere determined on the map and it was decided that the buildings on 14 site areas would be demolished and the regions would be organized as an openair museum. (Figure 1)

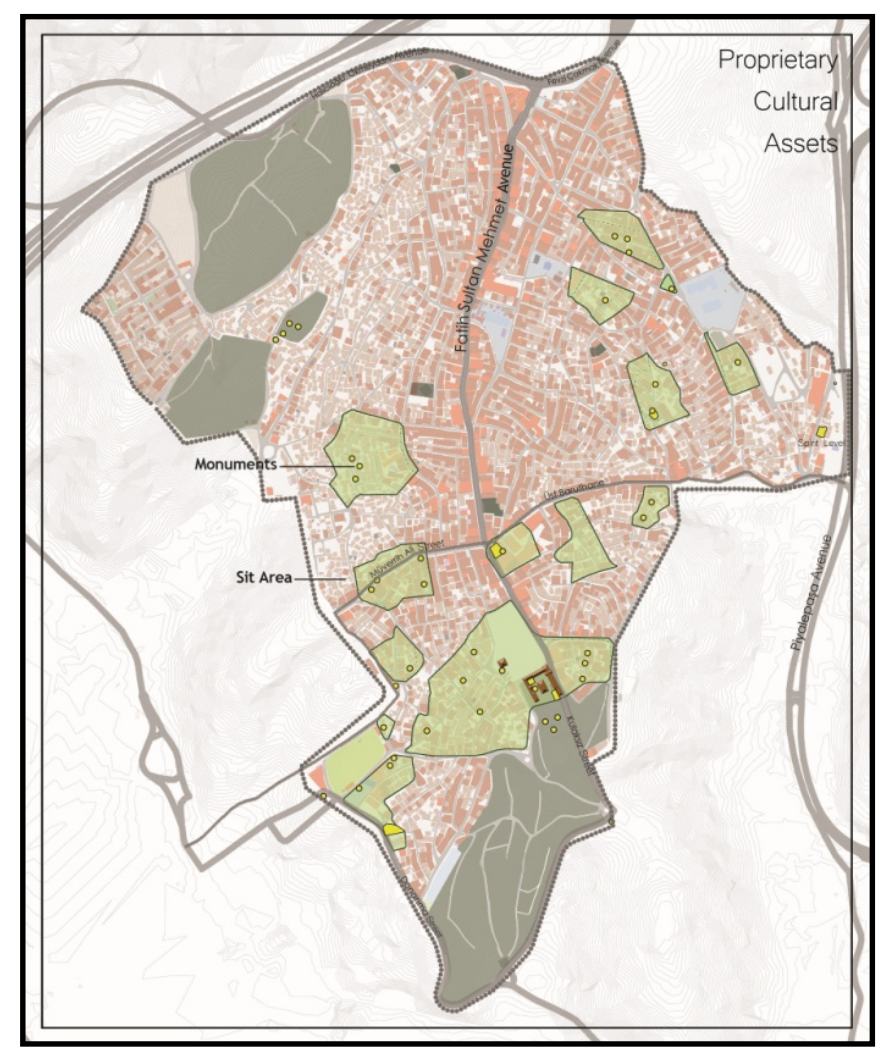

Figure 1. Sit areas and monuments in Okmeydanı 
According to the records of the Prime Ministry archives, the area size of Okmeydani during the conquest period was approximately 140 hectares. Today, Okmeydanı, which does not coincide with an administrative border, is a regionthat is within the boundaries of Beyoğlu (85\%) and Şişli (15\%). The parts of Okmeydanıthat remain in Beyoğludistrict consists of Fetihtepe and Piyelapaşa neighborhoods, and a part of Keçecipiri, Piripaşa, Kulaksız and Kaptanpaşa neighborhoods. (Figure 2)

Development of Okmeydanı started with the settling of the poor immigrants who came to Istanbul after the Balkan War of 1913(Bir et. al., 2006). The single-storeyhouses built by workers from the industrial areas around Haliçand shipyards at Kasımpaşa to meet their housing needs, expanded slowlytowards Okmeydanı via Hasköy and Kasımpaşa. Therefore, Okmeydanihas also started to be affected by the construction activities. However, Okmeydanı did not have a large construction activity until the 1950s. After this period, Okmeydanı was greatly affectedby the migration from rural to urban areas until the 1980s, and it was completely built up due to its closeness to the central business areas at that time (Eminönü, Beyoğlu, Şişli axis) and the intensity of industrial areas in the region. Constructions during this period were mostlylow-rise structures with gardens. After the 1980s, the construction continued uninterrupted, both in numbers and in floor height, until the 2000s. The policies implemented by local governments had a great influence on the structuring of this period. In the beginning, policies supporting developmentwere in favor, but later on prevention policies came into prominence. With the effect of the policies, there is almost no new construction after 1995. The structures that were builtby this time have largely come to the present day. (Figure 3) 

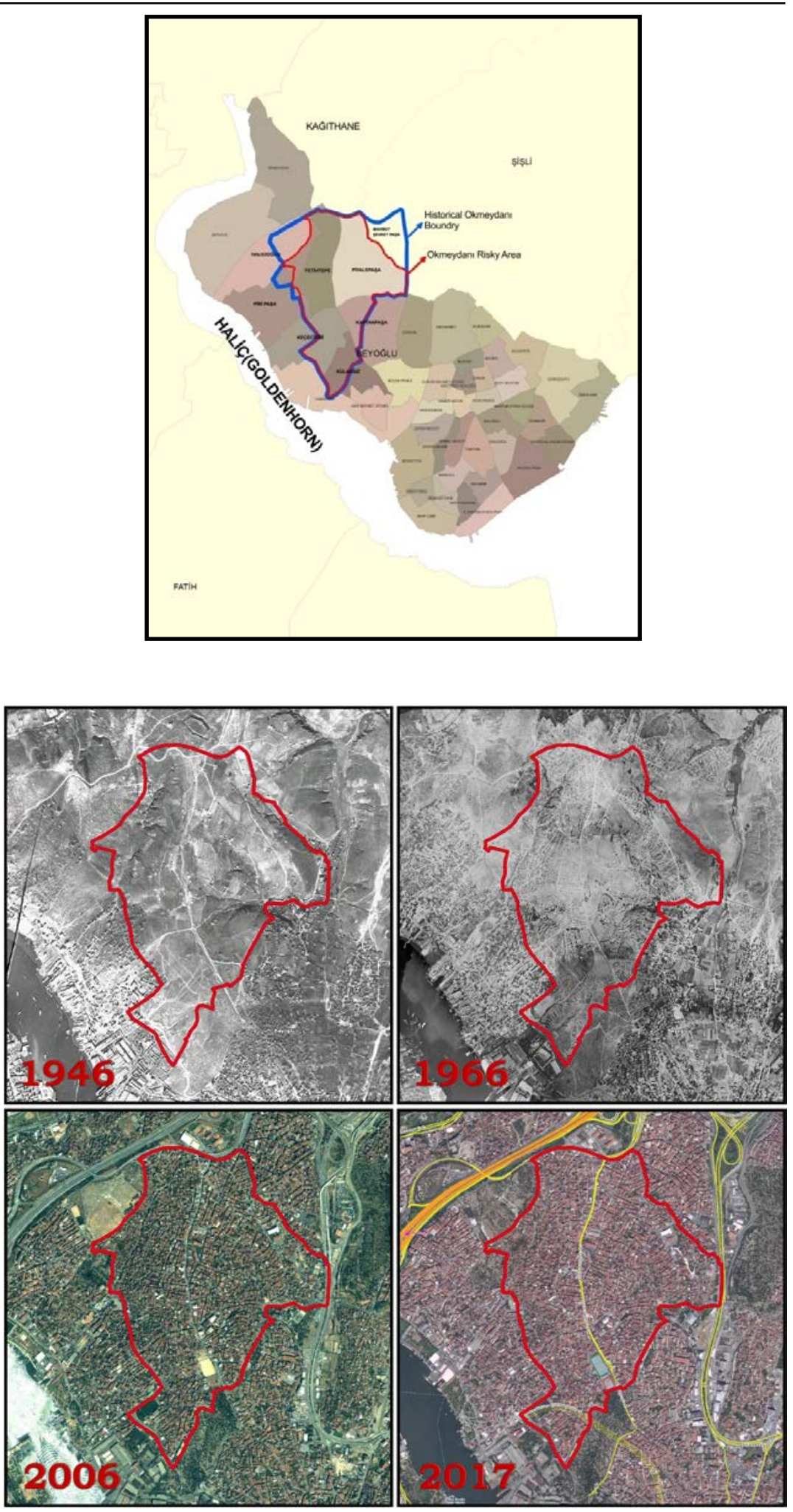

Planning tools used for development of Okmeydanı, which started in the 1950s and continued until the 2000s, were only The Reclamation Development Plan approved on April 25 1988, Parcelation Plan prepared in accordance with this plan and approved on 19 January 1989 by the decision of Beyoğlu Municipality Council and15th of December 1997 dated, 1/5000
Figure 2.0kmeydanı location

Figure 3. Periodic view of Okmeydanı construction process (1946-2017) 
and 1/1000 scaled master and implementary development plans for Dolapdere-Piyalepaşa Boulevard and Surroundings. However, Master and Implementation Development Plans were cancelled by a court decision 2 years later. Okmeydanı, where approximately 75,000 people live today, has no development plan prepared in accordance withmodern urban planning criteria and took its current shape with the randomness caused by the lack of inspections and only with the help of the Reclamation Development Plan.

The Master Plan and the Implementary Development Plan, prepared in accordance with the modern planning criteria and relevant legislation were approved on 13.08.2012 and 17.12.2012. These plans, whose primary aim is to improve the spatial, economic and social conditions in the region have been prepared by the central and local authorities in accordance with the planned urban transformation project targets for the whole region. In line with the target, arrangements for property were made simultaneously with planning. The first regulation is the sale of the lands occupied by the occupants in the field in accordance with the provisions of the Law No. 4706. The second one is the implementation of Article 18 of the Zoning Law No. 3194 in the region on 19.02 .2013 by the decision of the Municipal Council. Approximately 4300 parcels have been created with the improvement and parceling plans. These parcels were converted to 88 parcels with the smallest size of $3.550 \mathrm{~m}^{2}$ and the largest $35.035 \mathrm{~m}^{2} .32$ of these parcels are zoning parcels and the rest are urban facilities. The property of the parcels, which are allocated as urban reinforcement areas, is composed entirely of public and existing parcels belonging to the foundation. All rights holders in the region are included to the zoning parcels in the sense of ownership. With this arrangement, it is aimed that the right holders (48\%) remaining in the existing land or building, urban facilities or substructure area in the approved zoning plan will remain in the urban transformation project area. (Figure 4). These regulations on property ownership actually coincide with the idea that the inhabitants of the region, which are at the core of successful urban transformation practices, continue their lives in the same region. However, this arrangement made in Okmeydanı also means that the construction in the future cannot continue individually. 


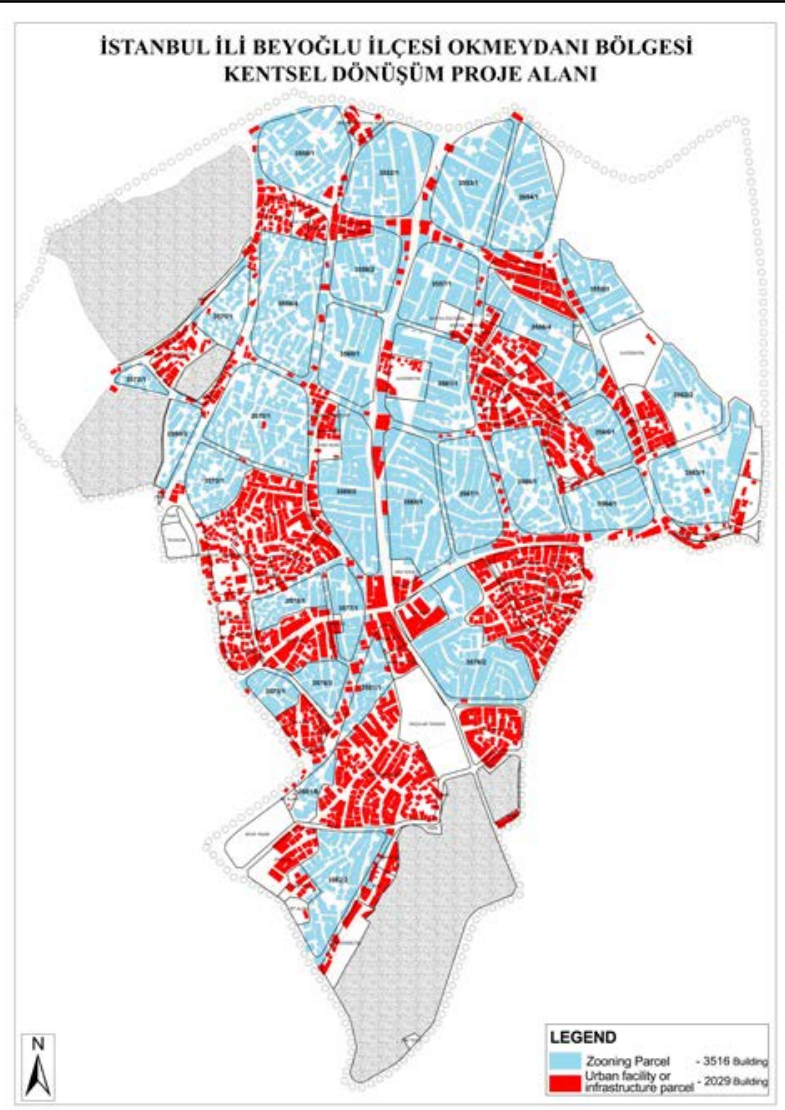

Figure 4. Urban Facilities in Zoning Plan of Okmeydanı (approved 2012)

Considering the quality and usage function of the existing building stock, it is almost imperative that the region is to be evaluated as a whole. The newest buildings (except for a few buildings) were built before the 2000s and they have expired their life cycle, both economically and technically. Furthermore, they were not subject to earthquake-based-construction obligations due to the fact that they were built before the 1999 Marmara Earthquake. Therefore, they are unlikely to be earthquake resistant. The ratio licensed buildings within the total number of existing buildings is approximately $0.1 \%$. Most of the buildings were constructed without any engineering services, using poor quality materials due to economic concerns, and without any controls in accordance with the local government policies of the period. Additionally, various reports by universities state that the region would be heavily damaged if the often mentioned great Istanbul earthquake were to take place(Gazi University, 2015). In this report, experts have come to this conclusion by analyzing the risk situation for all buildings and by performing a detailed analysis of a sufficient number of reinforced concrete and masonry buildings from varied risk groups. In the same report, it is emphasized that it is not possible to transform the buildings individually, and that the region should be evaluated as a whole. 
The need to act holistically is observed not only by considering the existing structure quality, but also by evaluating the physical properties of the buildings, location selection decisions and functions. In Okmeydanı where approximately 5550 buildings are located, $52 \%$ of the buildings are used as housing only, $40 \%$ as combined housing-commercialand $6 \%$ as commercial. Commercial use is mostly on the Fatih Sultan Mehmet Avenue, which is the main transportation axis of the region, and its parallel streets. The avenue divides the region in almost northsouth direction and it is a topographically a flat and long ridge. On the two slopes that fall from this ridge to the east and west, more usage as housingis observed. As it is understood from the statistical distribution of the functions, the number of buildings reserved as urban facilitiesin the region is negligible. Urban facilities in Okmeydanı, where the density of the population is higher than the district and the city average, consist of 9 religious facilities, 4 educational facilities, 3 administrative facilities and 2 health facilities. There are also 2 outdoor sports areas. All these buildings are far below the standards in terms of capacity and size. The facilities of the relevant institutions and the fact that they are built with local government policies also affects the productivity negatively and the location of the buildings is far from scientific analysis. (Figure 5)

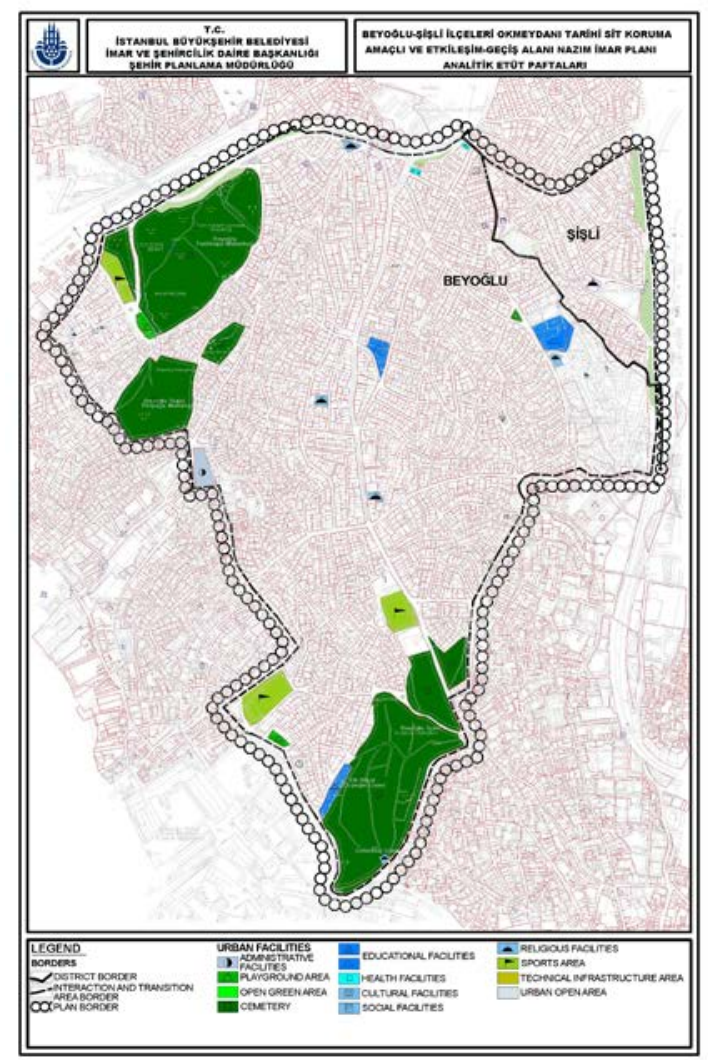


In commercial buildings, the number of floors is usually 4 or more, while the number of floors in residential buildings is less than 4 . Another determinant of vertical growth in buildings is the socio-economic structure of the people of the region. Some rights holders remained as one-storeysquatter $(28 \%)$ in the first construction, because they did not want to give up their garden structure in the regions they migrated, and others could not afford to make new construction economically. In case of need, additional building is constructed to the squatter in horizontal plane. But most of the buildings are shaped by adding an extra floor or rebuilding the existing buildings. One of the important determinants of the number of storeys is the number of children in the family. The social perspective of buildinga house for each child is one of the most common situations in Okmeydani. Houses built more than the number of children are generally constructed to obtain rental income. As a matter of fact, the ratio of tenants in the region is approximately $34 \%$ and the rate of free use is $8 \%$ depending on their relative relationship. In the construction, where socio-economic data are determinative and the construction period has spread over years, buildings are $69 \%$ reinforced concrete building and 31\% masonry construction system. The ratio of the floor areas of the buildings to the land area where they are located Floor Area Ratio(FAR) is 0,72. The ratio of the total construction area to the land area Gross Floor Area(GFA) is 2.93. These rates are an indicator of the high density of structures in the region.

Okmeydanı is far from offering the quality of life expected from large cities in terms of both infrastructure and upper structure inventory. This fact gives clues about the socio-economic condition of individuals living in Okmeydanı. The average household size (4 persons) in the region is greater than Beyoglu district (3.7 persons). The per person living areawhich should be at least $25 \mathrm{~m}^{2}$ according to scientific criteria, is $14 \mathrm{~m}^{2}$ in the region. The population between the ages of 15-64, except for the elderly and children groups, is $72 \%$, which is greater thanboth Beyoğlu and İstanbul. According to the survey of households, the biggest reason for settling in the region is that it is close to the job opportunities with a ratio of $78 \%$. Furthermore, $55 \%$ of those settled in the region with migration are from the Eastern Black Sea region, mainly from Giresun province, and 20\% from the Sivas, a central Anatolia region. The ratio of female and male population is almost the same. The highest level of education is the primary school with 58\%.The low level of education is reflected in the working life and thus the economy of the region. While $75 \%$ of the population work as wage earners, unfortunately $76 \%$ of those living in the region do not have social security. The largest business activity is wholesale and retail 
trade with $37 \%$. Accordingly, $68 \%$ of the age group suitable for work is unemployed. While $60 \%$ of the employees earn between 500-1000 Turkish Liras, the rate of employees with minimum wage is $12 \%$. Despite the advantage of being close to the city center and business opportunities, these findings are the greatest proof of the poor socio-economic conditions of the people of the region due to the high unemployment and low education level in Okmeydanı. All these data indicate that Okmeydani should be considered not only physically but also socially and economically as a whole in terms of urban transformation (İBB, 2012).

\section{Transformation Method and Value Based Mathematical Model}

Okmeydanı, which is declared a 'risky area' by the decision of the Cabinet, all construction related authority lies with the Ministry of Environment and Urbanization in accordance with the provisions of Law No. 6306. The Ministry delegated its authority to Beyoğlu Municipality in order to use the local dynamics more effectively and to speed up the implementation process. As a first step, the Municipality of Beyoğlu organized meetings to inform residents about the process of urban transformation. In almost 100 meetings, the subject of transformation has been discussed in terms of sociological, technical and administrative aspects by local residents, non-governmental organizations and expert teams. Expectations of the people of the region after the meetings were improvement of the construction quality in the region, increase in the number of urban facilities, not moving the current residents of the area to the another part of Istanbul, and not to be asked for resources during the construction process due to their poor economical conditions.

The transformation model was re-evaluated by the technical teams of Beyoğlu Municipality, taking into consideration the issues that stoodout in the meetings. In this context, the total construction area that can be implemented in the area was calculated first. Construction area that can be occupied in the whole area was calculated as $2.850 .000 \mathrm{~m}^{2}$ over the projects. In addition to this, with the parking area, technical areas and urban facilities areas, a construction area of approximately 4.500 .000 $\mathrm{m}^{2}$ is planned to be constructed within the scope of the transformation of Okmeydanı.

In the determination of the model of transformation implementation, the proposal of not asking for money at the construction stage was the decisive factor in the meetings held in the region. Considering the economy of the people of the region, this demand was welcomed by the administration and the idea that the construction process should be carried out directly by 
the government or by an investor in terms of the flat for land method has come to the forefront. However, the financial support provided by the ministry for the Okmeydanı Urban Transformation Project is just enough to use in matters such as reconciliation, determination of right owner, use of information technologies and rent assistance. Therefore, in the transformation of Okmeydanı, "flat for land" model was preferred in order to move quickly by taking the earthquake risk into consideration.

Exercising its authority, Beyoğlu Municipality met with investors from domestic and foreign countriesthat accept flat for land method and a protocol was signed with KIPTAŞ, who made the most appropriate offer. In fact, KIPTAŞ, as a semi-public company of Istanbul Metropolitan Municipality, approached the subject with a civic responsibility and kept the profit rate low. It has agreed to construct all buildings including urban facilities of $1.100 .000 \mathrm{~m}^{2}$, which corresponds to $38 \%$ of the total inhabited construction area in the region.In this context, it is possible to say that the transformation in Okmeydani was partly conducted by the state. However, considering the total size of the existing buildings in the area $\left(2,391,861 \mathrm{~m}^{2}\right)$, which will be distributed to the rights holders within the scope of the protocol, this means that the size of the area per owner will be reduced $\left(1,750,000 \mathrm{~m}^{2}\right)$. The average reduction ratio in Okmeydanı is around $28 \%$. This ratio differs from the mathematical model on the building scale by the cost value of the immovable owned by the right holders.

Within the scope of the protocol, $1.710 .000 \mathrm{~m}^{2}$ of the total inhabited area allocated to Beyoğlu Municipality has been distributed directly and $40.000 \mathrm{~m}^{2}$ of area has been reserved. Based on the principle of fairness, the allocation of $1.710 .000 \mathrm{~m}^{2}$ to be distributed directly to the rights holders is based on both the cost and market values of the real properties (buildings and land) owned by individuals. In order to determine the value, Cost Approach and Market Approach methods were used among different valuation models made by a CMB (Capital Markets Board) licensed company, taking into account the construction process and distribution model in the region(Harmoni, 2016). The results obtained by the Cost Approach method were used to determine the size of the residential or workplace to be offered to the rights holders, and the results obtained with theMarket Approach were used to make the location selection (betterment) of the designated residential or workplace.

The use of the reserve area $\left(40.000 \mathrm{~m}^{2}\right)$, which will be distributed indirectly to rights holders, is in two ways. The first is to compensate for the material errors that may occur during the measurements made within the scope of the distribution model. 
The second is an administrative decision to use in the improvements to be applied to one and two storey buildings in the area.Improvement ratesare formalized with the decision of the district council as. At least 35\% more than the existing structure area in 1-storey buildings, and to be at least the same with the existing building area in 2-storey buildings.

In the Cost Approach Method, the value of the real estate gets calculated in 2 stages. In the first stage, the cost value of the building is calculated. Approximate building unit cost groups (between 1A and 3B) determined by the Ministry of Environment and Urbanization were taken into account in the calculation. In addition, the depreciation rate (amortization) was taken into account by considering the construction years and physical conditions of the buildings. The following formula was used to calculate the structure value.

$$
\begin{aligned}
\text { Building Value }= & \text { Total construction area }\left(\mathrm{m}^{2}\right) * \text { Building unit } \\
& \operatorname{cost}\left(\mathrm{TL} / \mathrm{m}^{2}\right) *(1-\text { AmortizationRate })
\end{aligned}
$$

In the second stage, the land value of the building was calculated. In the calculation of land value, ownership status has been a decisive criterion. In the evaluation of a small number of privately-registered land, the entire land size was taken into consideration, while $72 \%$ of the land area was taken as the basis forthe valuation of land for non-registered lands. This ratio $(72 \%)$ is the average of the the floor areas of the buildings to the land area(FAR). Thus in Okmeydanı, where there is unplanned construction, a balance between the differences in horizontally random construction was desired. Another point to be taken into account when determining the value of the land was that if a building occupied more than one parcel, thetotal parcel area was taken into consideration in the valuation. In case there were more than one buildings in a parcel, the parcel values were calculated in accordance with a building's parcel usage ratio. For the fair market value of the land, the official figures determined by Beyoğlu Municipality are taken into consideration. The following Formula was used to calculate the value of the land.

$$
\begin{aligned}
\text { Land Value }= & \text { Land area of valuation }\left(\mathrm{m}^{2}\right) * \text { land market } \\
& \text { value }\left(\mathrm{TL} / \mathrm{m}^{2}\right)
\end{aligned}
$$

The value of the real property determined by the Cost Approach Method is equal to the sum of the land and building values detailed above in Okmeydanı. Total construction value of the 5552 buildings in Okmeydanı, which are calculated by the Market Approach, is 1.196.395.338 TL and the total value of the 
land is $375.107 .476 \mathrm{TL}$. Total real property value is calculated as 1.571.502.814TL.

The value determined by the Cost Approach method is equal to the size of the area to be given directly to the rightsholders. Thus, the square meter unit price of the conversion coefficient to be used in the offer of residential or workplace to be made to the right holders is calculated.

$$
\begin{aligned}
& \text { Conversion Coefficient }=\text { Total Cost of Real Estate } \\
& \text { Unit Price } \quad \text { Total Area to be Granted } \\
& \text { Directly to Rightsholders } \\
& =\frac{1.571 .502 .814 \mathrm{TL}}{1.710 .000 \mathrm{~m}^{2}} \\
& =919 \mathrm{TL} / \mathrm{m}^{2}
\end{aligned}
$$

Proposal for a building within the scope of the transformation over the unit price is calculated by dividing the cost value of the building by the unit price. The proposed area for the whole building is divided between the housing and commercial areas of the building in accordance with their current area share. The results are then rounded up to multiples of 5 and the area to be offered to the rights holders is thus finalized.

The other issues that were taken into consideration in the offers to the rights holders were determined by the Municipality of Beyoğlu. Accordingly, the smallest flat size is $50 \mathrm{~m}^{2}$. The difference in function does not affect the size of the offered area. In the approved zoning plans, considering the limitations imposed for the trade function, commercial area offers are made only for workplaces on the ground floor of the existing buildings. The offers for other rightsholders are the residential. Although it was not a part of the project in the beginning, in consideration of the criticisms and social dimension of the subject, it became possible to buy additional areas under special conditions. Accordingly, in case the flat offer to the rightsholders is less than $65 \mathrm{~m}^{2}$, a maximum of $15 \mathrm{~m}^{2}$ additional area can be purchased, provided that the totaldoes not exceed $65 \mathrm{~m}^{2}$. The possibility of purchasing additional space is only valid for the housing function.

The market (goodwill) values of existing buildingsare decisive in the selection of the housing or workplace to be offered to the rights holders in the transformation area. The market value was determined by the benchmark Market Approach at the house/workplace scale. This method has a three-stage calculation. In the first stage, the mean GFA value of the buildings in Okmeydanı (GFA: 2.93) was determined. When calculating the market value for each building, the construction area determined 
by this ratio is taken as the basis. In the second stage, separate goodwill score was determined for each structure. In the calculation of this score, the location of the building, the transportation relationship, the property information, unit cost group of the building and the physical condition criteria were taken into consideration. The participation of the criteria in the calculation method is $40 \%$ for the land location; $15 \%$ for transport relationship; $15 \%$ for building unit cost group; $5 \%$ for building condition; $25 \%$ for the ownership. Based on these criteria, goodwill score was determined asthe least at 4.29 and highest at 8.85. The average goodwill score in the region was 5.77. The average goodwill score was accepted as equal to the average unit sales value $\left(1200 \mathrm{TL} / \mathrm{m}^{2}\right)$ determined by examining the real estate sales in the area. The third stage is taken into account when the GFA value of the building is different from the average value. If the GFA value of the structure is more than the average GFA value, the construction cost area of the excess is calculated by adding the value to the value determined in the first and second stages. If it's less, the cost value of the missing part is subtracted from the value determined in the first and second stages and the final value is found. The formulas for all stages in calculating the market value of real property are as follows.

\section{1stStage;}

Calculated construction $=$ Land Area of the Building $\left(\mathrm{m}^{2}\right) *$ area Average GFA Value $(2,93)$

\section{2nd Stage;}

If land has average GFA value (main formula);

$$
\begin{aligned}
& \begin{array}{l}
\text { Calculated } \\
\text { construction } \\
\text { area }\left(\mathrm{m}^{2}\right)
\end{array}
\end{aligned} * \frac{\text { Building based goodwill score }}{\text { Average goodwill score }} * \begin{gathered}
\text { average unit } \\
\text { sales value } \\
\left(\mathrm{TL} / \mathrm{m}^{2}\right)
\end{gathered}
$$

\section{3rd Stage;}

If the structure is built on the average GFAvalue;

Mainformula $+[$ (actual construction area - calculated construction area) $\left(\mathrm{m}^{2}\right) *$ building unit cost $\left(\mathrm{TL} / \mathrm{m}^{2}\right) *(1-$ Amortazition Ratio)] 
If the structure is built below the average GFA value;

Mainformula - [(actual construction area - calculated construction area $\left(\mathrm{m}^{2}\right) *$ building unit cost $\left(\mathrm{TL} / \mathrm{m}^{2}\right) *(1-$ Amortazition Ratio)]

Method. According to the analysis made by a CMB licensed company, the new value in the post-transformation area will be approximately 25 billion Turkish liras. This value is expected to be divided between the rights holders and the investors by 50 $50 \%$. The total value of the dwellings or workplaces to be given to the rights holders over the rates is 12.5 billion Turkish liras. When this value is proportional to the current market value of the real estates owned by the right holders in Okmeydanı, an increase of approximately 4 times is observed. This rate of increase will be calculated separately on each zoning parcel and will be multiplied by the market value of the existing property of the rightholders and the maximum market value of the proposed area will be determined. The partner will select the proposed housing or workplace from this value or alternatives with less value.

$$
\begin{gathered}
\text { Offered } \\
\text { house/workplace } \\
\text { market value }
\end{gathered}=\begin{gathered}
\text { actual house } \\
\begin{array}{c}
\text { workplace market } \\
\text { value }
\end{array}
\end{gathered} * \begin{gathered}
\text { Value increase } \\
\text { rate in } \\
\text { zoning parcel }
\end{gathered}
$$

The summary of all the processes described above in relation to the distribution model to be used in the urban transformation application planned in Okmeydanı is as follows: The size of the house or workplace to be taken by the rights holders in the new project is determined by the cost values of the properties they own. The maximum market value of the house or workplace is determined by the market values. Both values of the rights holder are considered at the same time. After the urban transformation, the rights holder selects the housing or workplace alternative.

\section{CONCLUSION AND EVALUATION}

Okmeydanı is a region where urban transformation is inevitable due to its historical background, geographical location, construction process, unqualified building stock and socioeconomic structure. At the same time, the solution is unlikely without approaching the issue hollistically. Problems related to properties(about $75 \%$ are non-registered), and the implementation of Article 18 of the zoning law in the region, makes it impossible for individuals to act alone. For this reason, a construction activity in the region within the scope of the 
transformation directly concerns the rights holders outside the construction area. Therefore, it can only be a dream to wait for the right stakeholders to come together for the urban transformation of Okmeydanı, where approximately 75,000 people live. In this context, it is inevitable to organize the urban transformation centrally.

With the preferred transformation model in the region the expectations of the inhabitants of the urban transformation area were fulfilled and the forced displacement of the people of the region, which are frequently seen in urban transformation practices, was prevented. However, it is inevitable to send the right holders to different addresses in Okmeydanı from their current location. Furthermore, the high number of renters in the area might also mean that the residents will move to different areas. On the other hand, the fact that most of the tenants are second generation Okmeydanı residents means that they will most likely prefer to stay in the area and there will not be enough moving to change the social structure of the area.

It is the mostrational approach to have Beyoğlu Municipality which knows the region best to organize the urban transformation in Okmeydani, which is the second largest region in the 58 regions declared by the Ministry of Environment and Urbanization in Istanbul. It is also parallel to the determination that the transformation projects should be made by the public organization highlighted in the Urban Planning Council. At present, Beyoğlu Municipality has designed all the protocols of the process from the beginning. As it can be seen from the protocols, the fact that it does not profit from the new project and prefer the semi-public company with low profit rate as an investor clearly shows that the urban transformation is not made on the basis of income and is considered as a civic duty.In fact, according to the transformation model, while the area distribution rate of the new construction is to be between 38$62 \%$, determination of the $50-50 \%$ distribution of the value and thus maximizingthe size of the area to be offered to the rights holders by approaching the social transformation from a social point of view, and increasing the share of the investor in order to meet the financial needs for the completion of the project is a proof of thissituation.

Although Okmeydanı Urban Transformation Project is not an income-oriented transformation, it increases the density of the building due to the preferred transformation model. Additionally, the increase of urban facility areas in the region with the zoning plan means that the targeted construction areas for transformation can only be achieved by vertical growth, which in turn increases the density on building blocks. In spite of the increase in density, when Okmeydani is considered as a 
whole, there is no doubt that it will turn into a more livable place, but the burden of increasing density on the city will cause new problems. Therefore, a transformation project of this magnitude must be evaluated together with its environment. However, as there is not enough coordination between the relevant legislation and institutions, unfortunately the issue of transformation is limited only to the region where the riskyarea is declared, and its impact on the environment has not been analyzed.

In order to reduce the negative effect of the increase in density, all arguments, especially architectural project designs, should be used well. However, the transformation method and the distribution model developed accordingly restrict the ability of architectural projects. Because the distribution model through the total area size to be given to the right holders has been finalized. The use of scientific methods in the distribution of this area among the rights holders in terms of both interest and goodwill is a positive practice in terms of justice and transparency. However, as a result of the calculation, the acceptance of the fact that constant of the proposed area by the Beyoğlu Municipality increases the number of residential typologies in architectural projects. Moreover, the fact that the resulting housing typologies do not show a homogenous distribution makes architectural design extremely difficult. The issue of additional land purchasing, which is subsequently added to the distribution modelis culturally not very useful. This is because the minimum gross housing $(2+1)$ typology is too small. In addition, the fact that there is no reserve area other than the right holder and investor shares determined on the basis of the distribution model raises the question of where to buy the space to be given to those who want to benefit from this right. In this sense, the main principles of the distribution model should be reviewed. In addition to these, paying attention to the goodwill values in the choice of place of residence or workplace to be given to the right holders makes the process of the design very difficult. All these challenges can only be overcome by the architectural design teams, real estate appraisers who will make the new project appraisal and the concurrent work of the Beyoğlu Municipality officials who manage the reconciliation process. Howeverin a large area such as Okmeydanı, it is not possible to provide this co-operation long-term.

The difficulties in the preparation of architectural projects as well as the housing typologies emerged within the distribution model show that the issue is not analyzed well in the sociospatial sense. Given the existing family structure and size in Okmeydanı, housesoffered to the right holders arenot very useful in terms of current living standards. Especially the high 
amountof (1+1) typology flat offers (approximately 50\%) hinders possibility of living in the area for the rights holders sociologically. Additionally, the only possible way is expropriation in cases where the size is less than $50 \mathrm{~m}^{2}$ and the issue cannot be solved by means of partnership or purchase. In both cases, taking into account the increase in the value of the new project, the rights holders would prefer to sell their rights and indirectly abandon Okmeydanı. This result contradicts with the aim of keeping the people of the region after the transformation.

As a result, Okmeydani Urban Transformation Project is a project with no alternative other than approaching the technical and social data in a holistic manner. This project is generally a successful practice with the approach of the competent authority and its non-income-oriented approach through the target model. Although the preferred model for transformation in Okmeydani is supported and enriched by scientific methods, it unfortunately increases the building and population density in the region as in many urban transformation projects carried out in our country. Considering the magnitude of the region and decrease of the size of the rightholders house area ratio(28\%), it is difficult to predict when the reconciliation process, which forms the basis of the transformation, will be completed. This situation means that the risk of the transformation process is present until the end of the project and it may grow. It also increases the risk of paving the way for gentrification.

As long as Ministry of Environment and Urbanization does not meet the investor share out of determined reserves in the city for transformation projects with flat for land model, these problems for the cities will continue. After the bad experiences in developed countries, the idea of dealing with the subject only in physical dimension was abandoned. In a period when the situation is evaluated in terms of social, economic and environmental aspects, unfortunately, the transformation practices in our country are far from this reality. In the application of transformation projects, the subject is approached mostly with mathematical solutions on technical data, and the socio-economic and environmental dimension of the process is ignored. Therefore, especially in the surveys conducted in the transformation areas, questions regarding the future expectations of the residents in all aspects of their lives must be included, and they should even be made mandatory by law. If the transformation projects in our country are not addressed in a multifaceted and more meticulous way especially on their social and economical aspects, it will be much more difficult to transform our cities in the future. 


\section{REFERENCE}

Akkar Ercan, M. (2013). "Urban regeneration And sustainable community development in historic neighborhoods of Istanbul" pp. 443-454 in The Routledge Companion To Urban Regeneration, edited by M.E. Leary and J. McCarthy, New York: Routledge

Atkinson, R. (2004). "Kentsel Dönüşüm, Ortaklıklar ve Yerel Katılım: İngiltere Deneyimi", Uluslararası Kentsel Dönüşüm Uygulamaları Sempozyumu, 27-30 Kasım 2004, Türkiye

Auerbach, G. (2013) "Urban politics and public policy-Looking back and going forward: 'Project Renewal in one Israeli City, Cities", Cities, 31, 197-207.

Bir, A , Kaçar, M , Acar, Ş . (2006). "Türk Menzil Okçuluğu, Yay ve Okları", Osmanlı Bilimi Araştırmaları, 8 (1), 39-67

Beswick, C.A. and Tsenkova, S. (2002). "Overview of urban regeneration policies" pp. 9-16 in Urban Regeneration Learning from the British Experience, edited by $\mathrm{S}$. Tsenkova, Calgary: Faculty of Enviromental Design University of Calgary

Carmon, N. (1999). "Three generations of urban renewal policies: analysis and policy implications", Geoforum, 30(2), 145158.

Clay P.L. (1979). "Neighbourhood Renewal: middle-class resettlement and incimbent upgrading in American neighborhoods", Toronto: Free Press

Couch, C. (1990). "Urban renewal, Theory and Practice", London: Macmillan Education.

Couch, C. and Fraser, C. (2003). "Introduction: the European Context and Theoretical Framework " pp. 1-16 in Urban Regeneration in Europe. edited by C. Couch, C. Fraser and S. Percy. Blackwell Science, Oxford Real Estate Issues.

Couch C., Sykes O. and Börstinghaus W. (2011). "Thirty years of urban regeneration in Britain, Germany and France: The importance of context and path dependency" Progress in Planing, 75(1), 1-52

Couch C., Sykes O. and Cocks M. (2013). "The Changing Context Of Urban Regeneration In North West Europe" pp. 33-44 in The Routledge Companion To Urban Regeneration, edited by M.E. Leary and J. McCarthy, New York: Routledge

Diacon D. (1991). "Deterioration of the Public Sector Housing Stock", England: Gower Publishing

Donnison, D. (1993). "The Challenge of Urban Regeneration for Community Development" , Community Development, 28(4): 293-298

Fraser C. (2003). " Change in the European Industrial City " pp. 17-33 in Urban Regeneration in Europe, edited by C. Couch, C. Fraser, S. Percy, Malden: Blackwell Publishing

Gazi Üniversitesi, (2015). "İstanbul İli Beyoğlu İlçesi Okmeydanı Riskli Alan Teknik Raporu, İstanbul

Hague, C. (2004). "Konut Alanlarında Dönüșüm ve Konut Alanları Yenileme Projelerinin Bașarılması", Uluslararası Kentsel 
Dönüşüm Uygulamaları Sempozyumu, 27-30 Kasım 2004, Türkiye

Harmoni, (2017). "İstanbul İli, Beyoğlu İlçesi, Fetihtepe-PiripaşaPiyalepașa-Keçecipiri-Kaptanpașa-Kulaksız Mahalleleri (Okmeydanı Kentsel Dönüşüm Projesi)- Değerleme Modellemesi Açılkama Raporu", İstanbul

Harvey D. (1987). "Flexible Accumulation Through Urbanızation: Reflections On 'Post-Modernism' In The American City", Antipode, 19 (3), 260-286.

İBB, (2012). "Okmeydanı Tarihi Sit Alanları Koruma Amaçlı ve Etkileşim Geçiş Sahası 1/1000 Ölçekli Uygulama İmar Planı Açıklama Raporu", İstanbul

Kennedy M. and Leonard M. (2001). "Dealing With Neighborhood Change: A Primer Gentrification and Policy Choises", A Discussion Paper Prepared for the Brockings Institution Center on Urban and Metropolitan Policy, US.

Koebel C.T. (1996). "Urban Redevelopment, Displacement and the Future of the American City", in Community Affairs Office Federal Reserve Bank of Richmond, Virginia

Lees, L. (2007). "Vision of 'Urban Renaissance' the urban task force report and the urban white paper", pp. 61-82 in Urban Renaissance? New labour, community and urban policy, edited by R. Imrie and M. Raco, Bristol:The Policy Press

Moseley, J. (2006). https://www.building.co.uk/10-ways-todefine-regeneration/3062794.article

Oc T., Heath T. and Tiesdell S. (2010). "Desing in Historic Quarters", Rivista di Scienzedel Turismo, 1(2), 51-74

Pacione M. (2001). "Urban Geography: A Global Perspective", New York: Routledge

Roberts P. (2000). "The Evolution, Definition and Purpose of Urban Regeneration" pp. 9-37 in Urban Regeneration A Handbook, edited by P. Roberts and H. Sykes, Thousand Oaks, New delhi: Sage Publications

Rui L. (2003). "Urban Renewal at Neighbourhood Level A Case Study at Huangjiadun Neighbourhood in Wuhan City", MSc in Geoinformation Science and Earth Observation with Specialization in Urban Planning and Management, ITC, Hollanda.

Teixeira, J.M. (2010). "Urban Renessaince : The Role Of Urban Regeneration inEurope' s Urban Development Future", Serbian Architectural Journal, 711(4), 97-114

Thomas, S. (2003). "A Glossary of Regeneration and Local Economic Development", Manchester: Local Economic Strategy Center.

Torus, B. and Aydın Yönet, N. (2016). "Urban Transformation in İstanbul. Archi-Cultural Interactions Through the Silk Road" 4.th International Conference, 16-18 July 2016, pp. 126-129, Japan

Verhage, R. (2005). "Renewing urban renewal in France, the UK and the Netherlands: Introduction", Journal of Housing and Built Environment, 20(3), 215-227.

Visscher, H., Gruis V. and Kleinhans, R. (2006). "Introduction" pp. 1-18 in Sustainable Neighbourhood Transformation, 
edited by V. Gruis, H. Visscher, R. Kleinhans, Amsterdam: IOS Press

Yalpır, Ş., (2007). "Bulanık Mantık Metodolojisi ile Taşınmaz Değerleme Modelinin Geliștirilmesi ve Uygulaması: Konya Örneği", Doktora Tezi, Selçuk Üniversitesi, Fen Bilimleri Enstitüsü, Konya

Zheng, W.H., Shen, G.O., Wang, H. (2014). "A review of recent studies on sustainable urban renewal", Habitat International, 41, 272-279.

\section{Resume}

Ufuk Altunbaş graduated in 2001 from Istanbul Technical University City and Regional Planning department. He completed his master's degree on "The Effects of Pedestrianization in the City Centres on Functional Evaluation: Study of İstiklal Street" in 2006 and his doctorate on "The Effect of Physical and Socio-Spatial Factors on Children Driven to Crime" in Istanbul Technical University in 2015. He started his professional career in Beyoğlu Municipality in 2002 and continues his career as an Urban Transformation Manager in the same municipality. 